\title{
THE PREVENTION OF RADICALIZATION, VIOLENT EXTREMISM, AND TERRORISM THROUGH THE REPUBLIKA SRPSKA EDUCATION SYSTEM
}

Original Scientific Paper

\begin{tabular}{|l|l|l|}
\hline DOI 10.5937/zurbezkrim1902025S & COBISS.RS-ID 8631064 & UDK 37.014.5:321.64]:323.28 \\
\hline
\end{tabular}

\author{
Milica Sikimić ${ }^{1}$ \\ Faculty of Security Studies, University of Banja Luka \\ Velibor Lalić \\ Faculty of Security Studies, University of Banja Luka \\ Predrag Ćeranić \\ Faculty of Security Studies, University of Banja Luka
}

\begin{abstract}
Education is a source of knowledge about social phenomena and processes and plays a significant role in the prevention of socially harmful behaviors. This paper analyzes the extent to which educational content about radicalization, violent extremism, and terrorism in elementary, secondary, and higher education (public universities) is present, and the extent to which envisaged teaching topics are tailored to the current security environment. According to the keywords "radicalization", "violent extremism" and "terrorism", the curricula for all three levels of education in the Republika Srpska were analyzed and quantitative and qualitative analyses were conducted thereafter. The research findings demonstrated that the topics of radicalization, violent extremism, and terrorism are not addressed in primary and secondary education. Regarding higher education, there is a clear lack of courses in this field within many study programs. Topics in the study of terrorism have largely remained peripheral within the Republika Srpska education policy.
\end{abstract} vention.

Keywords: radicalization, violent extremism, terrorism, education, pre-

\section{INTRODUCTION}

Although police and security services and criminal justice agencies are directly concerned with the issues of radicalization, violent extremism, and terrorism, these phenomena should be the subject of interest to the entire society. The use of repressive actions to suppress them is unavoidable. However, repressive measures, if they are not accompanied by preventive actions, cannot produce long-term and sustainable results (Thomas, 2016). Education system can play a very important role in the prevention of these socially destructive phenomena. Youth is a particularly vulnerable category to various forms of manip-

\footnotetext{
1 Corresponding author: Milica Sikimić, MA, Teaching Assistant, Faculty of Security Studies, University of Banja Luka. E-mail: milica.sikimic@fbn.unibl.org
} 
ulation and indoctrination, especially through modern information technologies. The dissemination of extremist ideas and radicalization through the Internet is a widespread phenomenon. According to the United Nations, the number of children recruited and exploited by terrorist organizations has increased in recent years. The prevention of child recruitment is a comprehensive process requiring the integration of knowledge and multiple approaches from different fields (UNDOC, 2017).

Police officers are often unable to become actively involved in preventative activities, primarily because they are overwhelmed with operational tasks. This provides an opportunity for education system to enable young people to acquire basic knowledge of radicalization, violent extremism, and terrorism through educational processes. Education can help young people to develop interpersonal skills to respond to changes and disagreements with others with calm, to question legitimacy and justification as well as the views proclaimed by terrorist organizations, which can also help develop their resistance to violent action. ${ }^{2}$

Education in the area of security poses a major challenge to every society. In this respect, it is crucial that teaching activities are delivered by quality teaching staff at all levels of education. In this regard, there is a need for attractive curricula with clear educational goals, which are socially justified (Mijalković, 2014).

The prevention of extremism and terrorism is of great importance in every society, especially in Bosnia and Herzegovina $(\mathrm{BiH})$ - a post-conflict country faced with these problems to a significant extent (Azinović, 2012). Islamic fundamentalism and terrorist acts in Bosnia and Herzegovina $(\mathrm{BiH})$ are a social reality, even though this problem has been minimized and relativized by certain $\mathrm{BiH}$ political elites and a portion of the public.

A review of the relevant literature revealed the papers addressing the ontological, epistemological, and methodological issues in the field of terrorism studies (Reid, 1997; Silke, The Devil you Know: Continuing Problems with Research on Terrorism, 2001; Gordon, Applying Analytical Methods to the Study of Terrorism, 2004a; Jackson , 2012; Gordon, Terrorism and Knowledge Growth: A Databases and Internet Analysis, 2004b; (Sheehan, 2012; Mahoney, 2017; Altran, Axelrod, Davis, \& Fischhof, 2017; Schuurman, 2018). These aspects relate to the creation of knowledge of terrorism, while the issues related to the dissemination of this knowledge in the educational sector, which is a very important aspect, have been significantly neglected (Mušić, 2016; Mijalković, 2014; Sheehan, 2012; Gordon, Applying Analytical Methods to Study Terrorism, 2004a). The literature review did not reveal similar studies on the prevalence of the topics related to radicalization, violent extremism, and terrorism in the educational process.

This study is exploratory in nature, so it was not possible to compare our findings with the findings of previous studies in the region and beyond. The aim of this paper is to determine the extent to which educational content about radicalization, violent extremism, and terrorism in primary, secondary, and higher

\footnotetext{
2 The UNESCO Teacher's Guide on the Prevention of Violent Extremism suggests discussing local manifestations of radical extremist views with students rather than discussing its international forms. Discussing this phenomenon helps young people to understand the links between local and global challenges and the real risks and consequences of terrorism. Further, the teacher should be the moderator and objective to social, cultural, ethnic and other diversity in the local context and, of course, a person who possesses prior knowledge of violent extremism and terrorism (UNESCO, 2016: 13-17).
} 
education (at public universities) is represented in the Republika Srpska and how the current subject contents meet practice.

This study is focused on two basic research questions: (1) the extent to which the topic of radicalization, violent extremism, and terrorism is studied in the public education system in the Republika Srpska and (2) whether the current curricula are adapted to social needs and the security environment we are facing.

\section{METHODOLOGY}

The content of curricula used by public educational institutions in the Republika Srpska was analyzed. The primary, secondary, and higher education curricula were analyzed. The Republika Srpska Ministry of Education and Culture, that is, the Republican Pedagogical Institute draws up primary and secondary education curricula in the Republika Srpska. The curricula set out the subjects, class schedule, the annual and weekly number of classes, as well as the content to be taught (Republican Pedagogical Institute, 2019). In the Republika Srpska, higher education is carried out in public and private institutions of higher education, which perform their activity according to different curricula (Republika Srpska Higher Education Law, Articles 11-24, RS Official Gazette $73 / 10 ; 104 / 11 ; 84 / 12 ; 108 / 13 ; 44 / 15 ; 90 / 16$ and $31 / 18)$. Given that the focus of this paper is placed on the representation of course contents on radicalization, violent extremism and terrorism, the curricula used by two public universities, the University of Banja Luka and the University of East Sarajevo, in the Republika Srpska were analyzed. The curricula were analyzed based on the following keywords: radicalization, extremism, and terrorism. After identifying the keywords, quantitative and qualitative analyses of the curricula were performed. Additionally, the contents that could indirectly relate to the prevention of violence having a political, national, ethnic, racial or similar connotation was analyzed. The analysis of the content of the curricula revealed quantitative indicators, that is to say, a set of lessons taught at primary and secondary schools, and the institutions of higher education, and qualitative indicators, that is, the content of teaching units covering the topics of extremism and terrorism.

\section{PRIMARY AND SECONDARY EDUCATION CURRICULA IN THE REPUBLIKA SRPSKA}

In the Republika Srpska, the Republican Pedagogical Institute ${ }^{3}$ is responsible for adopting primary and secondary education curricula. The curricula contain the names of the subjects, subject content and the number of teaching hours (Republican Pedagogical Institute, 2019).

The curriculum for elementary education in Republika Srpska provides for the following subjects: Serbian (the languages of the Bosniaks and the Croats); Orthodox Religious Education; first foreign language; second foreign language; Art; Music; Nature and Society; Knowledge of Nature; Knowledge of Society; History; Democracy and Human Rights; Geography; Physics; Mathematics;

3 Republican Pedagogical Institute is an administrative organization within the Ministry of Education and Culture. 
Biology; Chemistry; Technical Education; Computer Science; Physical Education; My Surroundings; Speech, Expression, Creation; Physical education, rhythmic, music; homeroom classes (Republican Pedagogical Institute, 2019).

The analysis of the curricula revealed that they did not encompass any topics which are directly related to radicalization, violent extremism and terrorism. However, some course programs address the topics that aim to develop tolerance and respect for cultural diversity. Such a content has been found in the educational plans for the subject Orthodox Religious Education and homeroom classes. As an example, we cite an excerpt from the program for the Orthodox Religious Education course that relates to the course objectives: "developing a sense of personal responsibility and self-conscious obligation, so that they can properly choose between good and evil as basic moral categories; and "developing a proper attitude toward a family and society and people who live, think, and believe differently." Upon completion of the course, students are expected to "recognize the difference between good and evil" and "explain the importance of doing good deeds and avoiding bad deeds" (Republican Pedagogical Institute, 2019). Also, the planned topic of violence prevention is taught in homeroom classes in most grades, to help students recognize violent behaviors, differences as a cause of violent behavior, and develop socially acceptable patterns of behavior according to individual and group differences (Republican Pedagogical Institute, 2019).

Regarding secondary education in the Republika Srpska, according to the Republican Pedagogical Institute data, a total of 13 professions and the Grammar school offering four programs are available to students who graduate from the primary school (Republican Pedagogical Institute, 2019). The analysis of the subject contents did not identify those directly or indirectly addressing the topics of radicalization, violent extremism or terrorism.

\section{STUDY PROGRAMS AT THE FIRST LEVEL OF STUDIES AT PUBLIC UNIVERSITIES IN THE REPUBLIKA SRPSKA}

There are two public universities in the Republika Srpska: The University of Banja Luka and the University of East Sarajevo, and their programs at the first level of studies have been analyzed for the purpose of this research.

\section{University of Banja Luka}

A leading higher educational institution in the Republika Srpska, and the second largest institution in $\mathrm{BiH}$, is the University of Banja Luka, which has 17 faculties with 58 first-cycle study programs, 65 second-cycle study programs and 9 third-cycle study programs (University of Banja Luka, 2019). The first-cy-

28 cle study programs at the Faculty of Law and the Faculty of Security Studies were analyzed, that is, the faculties on whose websites course contents which could be linked to radicalization, violent extremism and terrorism were found.

In the curriculum used by the Faculty of Law, University of Banja Luka, three courses addressing the mentioned content were found - Criminal Law, Criminology with Penology, and Organized Crime. In the second year of study, 
more precisely in the third semester, Criminal Law with the unit "Terrorism-related offenses" is a compulsory course (Faculty of Law, 2019). Criminology with Penology is a compulsory course in the third year of study, and students should acquire knowledge "in the area of criminal etiology and phenomenology, as well as in the area of penology." The subject content of Criminology with Penology does not include the term "terrorism". However, some of the envisaged teaching units address the etiology of crime, especially its economic, political, and ideological factors (Faculty of Law, 2019). In the fourth year of study, students can opt for an elective course - Organized Crime which includes the topic "Determining money-laundering methods used by organized crime and the methods of funding terrorist activities", and the required level of knowledge should enable students to better understand organized crime and contemporary security challenges, risks, and threats (Faculty of Law, 2019).

The Faculty of Security Studies (former College of Internal Affairs) was created in 2017 in Banja Luka within the Ministry of the Interior of the Republika Srpska. Currently, courses are taught according to the old and new study program Security and Criminal Sciences, with two study options - criminal justice and forensic science (criminalistics), and students opt for one in the third year of study. The old study program offered by the College of Internal Affairs is still being attended by the students admitted to the College prior to the 2017/18 academic year, while the new study program is being attended by the students admitted to the College after the 2017/18 academic year (Faculty Summary, 2019).

During the study program at the College of Internal Affairs, students were first introduced to the term terrorism in the second year of study, as part of the compulsory course Methodology of Criminalistics. The unit "Terrorism - International Terrorism" occupied three teaching hours and two practical classes, in which the students acquired knowledge of the concept, characteristics, types, and manifestations of terrorism, the means and methods of commission and knowledge of terrorism-related offenses committed, the detection and capture of terrorists, as well as the characteristics and manifestations of international terrorism (College of Internal Affairs, 2012). Organized Crime encompassing the unit Organized Crime and Terrorism is a compulsory course in the third year of study, which is held $3+2$ hours on a weekly basis (College of Internal Affairs, 2012), while in the seventh semester of the Criminal Science course, four teaching hours are devoted to cyber terrorism within the elective Cyber Crime course, which includes topics such as the definition of cyber terrorism, its characteristics, the profile of cyber terrorists and the ways of counteracting this type of terrorism (College of Internal Affairs, 2012).

The criminal justice program contains three courses dealing with terrorism, but none of these subjects is compulsory. The syllabus of the Intelligence and Security Services course envisages a total of eight teaching hours (four lectures and four practical classes) addressing the topic of extremism and terrorism, the concept and types of domestic extremism and terrorism, extreme political and terrorist organizations, international terrorism, and the forms of manifestation of extremist and terrorist activity. This teaching topic also covers totalitarianism, extreme nationalism and separatism, illegal organizing and banditry, conspiracy-coup actions, the individual acts of violence, civil war provocation, and foreign interventions. Other teaching units that can be associated with the subject of this paper are ideological-political indoctrination 
and religious fanaticism (College of Internal Affairs, 2012). The elective course Security and Protection System gives students an opportunity to learn about the concept of terrorism, the characteristics and manifestation of terrorism, as well as the structures of terrorist organizations during a total of four teaching hours (College of Internal Affairs, 2012). Students were also given an opportunity to choose to attend the 60-hour optional course Terrorism (30 lectures and 30 practical classes), and the objective of taking this course is to acquire basic knowledge about globalization and terrorism and its application; the forms and content of organizing terrorist organizations, the new forms of terrorism and the fight against terrorism (College of Internal Affairs, 2012).

All students who enrolled in the first year of study in the 2017/18 academic year and thereafter attend the Security and Criminal Sciences 2017/18 study program. The curriculum has been modified with new, up-to-date content in line with changes in the security environment. Mastering some (compulsory) subjects requires knowledge of terrorism and the number of teaching hours has been increased significantly. Already in the first semester, a total of six teaching hours has been envisaged for teaching the course Fundamentals of Security Sciences intended to familiarize students with terrorism as a national and international security threat (Faculty of Security Sciences, 2019). The curriculum for the Defendology course, which studies contemporary security studies, provides a total of 6 teaching hours ( 4 lectures and 2 practical classes) on for the topic of terrorism as a threat to the political security sector (Faculty of Security Studies, 2019). A significant novelty is that the new curriculum envisages the courses Terrorism, and Intelligence and Security Services as compulsory courses (Faculty of Security Studies, 2019). Compulsory courses Global Security and Critical Infrastructure Protection were not analyzed because that they are not available yet under the new study program and changes to the submitted syllabuses are possible, and they were not encompassed by the previous 2014/15 study program.

A review of the teaching hours revealed that, at the Faculty of Law, a minimum of 13 and a maximum of 17 (through elective courses) are devoted to terrorism. At the Faculty of Security Studies, according to the 2014/15 curriculum, students have to attend minimum 10 and maximum 82 classes, while students studying according to the 2017/18 curriculum have to attend 110 classes devoted to topics on various aspects of terrorism.

Table 1. Overview of the number of teaching hours devoted to the topics of radicalization, violent extremism and terrorism - within study programs taught at the University of Banja Luka

UNIVERSITY OF BANJA LUKA

\begin{tabular}{|c|c|c|}
\hline \multicolumn{3}{|l|}{ Faculty of Law } \\
\hline Course Title & Type of Course & Number of teaching hours devoted to terrorism \\
\hline Criminal Law & Compulsory & 7 \\
\hline $\begin{array}{l}\text { Criminology with } \\
\text { Penology }\end{array}$ & Compulsory & 6 \\
\hline Organized Crime & Elective & 4 \\
\hline
\end{tabular}




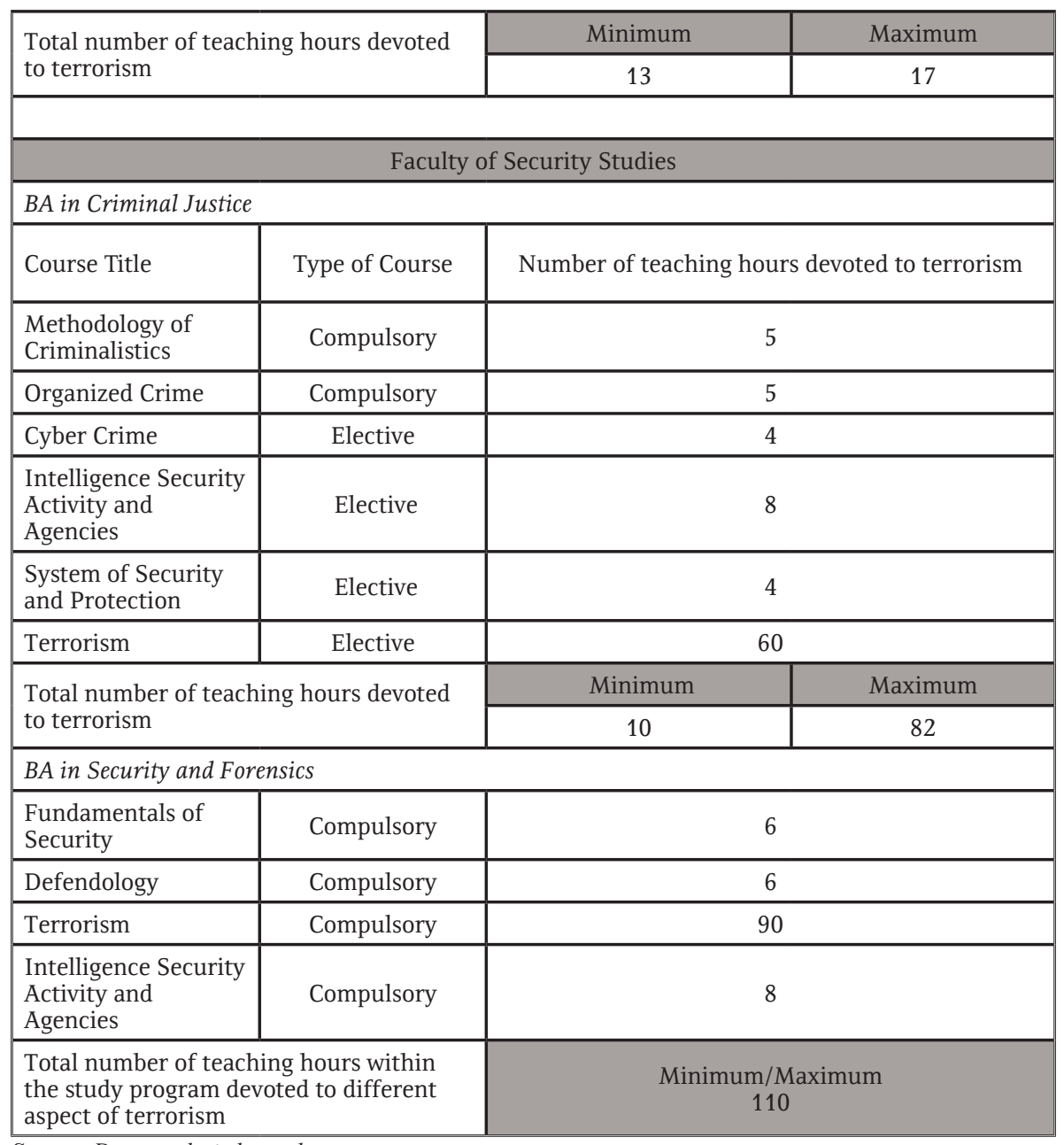

Source: Data analysis by authors

\section{The University of East Sarajevo}

The University of East Sarajevo consists of 17 organizational units with 56 study programs at the bachelor's level (first cycle), 48 at the master's level (second cycle), and 11 at the doctoral level (third cycle) (University of East Sarajevo, 2019). Although undergraduate courses at the law faculties within public universities in the Republika Srpska are not identical, in the Criminal Law and Criminology with Penology courses at the Faculty of Law in East Sarajevo, we find the same topics as well as the topics already mentioned in the same courses at the Faculty of Law in Banja Luka, which will not be discussed again. The difference is that Organized Crime is not envisaged as a course at the Faculty of Law in East Sarajevo (Faculty of Law, 2019). 
Teaching units on violent extremism and terrorism were found within several study programs offered by the Faculty of Philosophy. Within the study program Journalism in the fourth year, the compulsory course International Relations envisages a total of $5(3+2)$ teaching hours devoted to the topic "Terrorism and International Relations" (Faculty of Philosophy, 2019). Elective course within the study program Political Science and International Relations - International major, 5 teaching hours $(3+2)$ are envisaged for the teaching unit Challenges of Extremism, Terrorism in the EU and $\mathrm{BiH}$ within the EU and BiH's foreign police course (Faculty of Philosophy, 2019). The study program Sociology within the Contemporary Political Systems course addresses the topic "EU's policy in the area of freedom, security and counter-terrorism" (Faculty of Philosophy, 2019).

Other content on the topic of radicalization, violent extremism, and terrorism were not found.

Table 2. Overview of the number of teaching hours devoted to the topics of violent extremism and terrorism - within study programs taught at the University of East Sarajevo

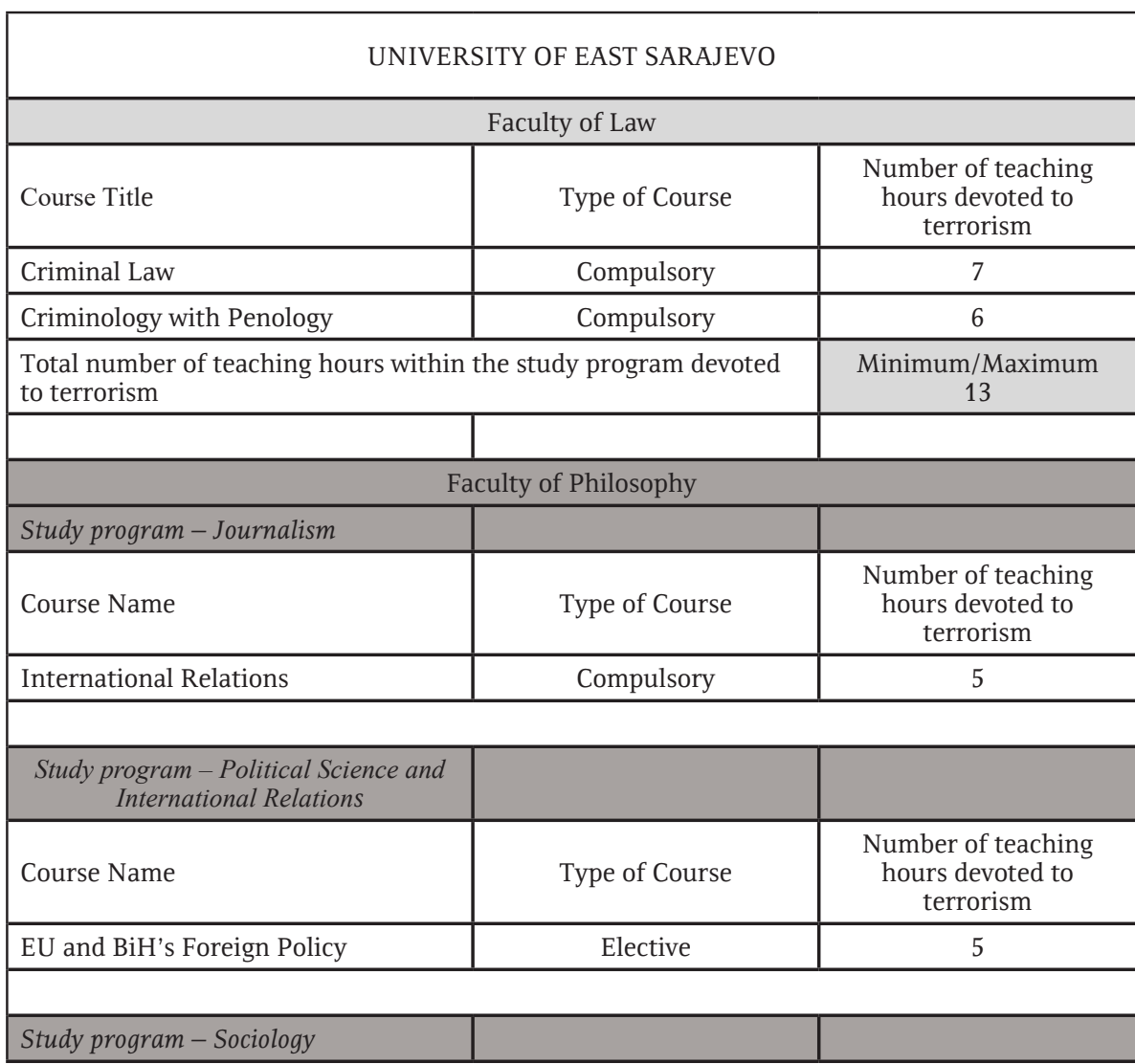




\begin{tabular}{|c|c|c|}
\hline Course Name & Type of Course & $\begin{array}{c}\text { Number of teaching } \\
\text { hours devoted to } \\
\text { terrorism }\end{array}$ \\
\hline Contemporary Political Systems & Elective & 4 \\
\hline
\end{tabular}

Source: Data analysis by authors

The review of course load found 13 teaching hours at the Faculty of Law and a total of 14 teaching hours within the three study programs offered by the Faculty of Philosophy, University of East Sarajevo.

\section{DISCUSSION}

Does public education in the Republika Srpska appropriately empower young people to understand the contemporary social environment and to recognize the dangers of radicalization, violent extremism and terrorism? Bosnia and Herzegovina, including some other parts of the Western Balkans (Europol, 2017), faces the problem of radical Islam. This problem in Bosnia and Herzegovina is significantly evident (Azinovic \& Jusic, The New Call to the War in Syria and the BiH Contingent of Foreign Fighters, 2019; Prislan, Chernigoj, \& Lobnikar, 2018) and deserves the attention of practitioners, researchers and the public at large. The currentness of this issue demands that an appropriate place to educate new generations at all levels of education be found within the education policy of the Republika Srpska.

In relation to the subject content that addresses the topics of radicalization, violent extremism, and terrorism, the role of education in the Republika Srpska can be viewed from two basic perspectives. The first refers to primary and secondary education, during which students should become familiar with the basic characteristics of these phenomena and the threats they generate. It should aim at raising the security culture of young people to a higher level, so that young people may acquire proper knowledge to recognize threats and respond to them appropriately (Stajić, Mijalković \& Stanarević, 2006; Stanarević \& Bodin, 2014). This segment of education is of primary importance. Young people, on the other hand, learn to value cultural diversity and resolve disputes during their education (be it individually or at the level of social groups) exclusively in a peaceful way, through dialogue and tolerance.

In the context of higher education, the topics of radicalization, violent extremism, and terrorism are of great importance for preparing prospective graduates to be sufficiently trained in their professional work to cope with professional challenges in an increasingly precarious social environment. This knowledge is not exclusively intended for professional members of the security sector or criminal justice, but also for employees in other sectors, such as the media (Nacos B., 2016), social work centers (Ragazzi, 2017), public administration (Hague, 2002), research centers (Dongen, 2018), and so on. The range of activities is broad and covers all segments of social life.

The research findings demonstrated the extent to which these contents are studied and meet the needs of society. First, primary and secondary education curricula is reviewed. The research findings demonstrated that the subject 
contents related to radicalization, violent extremism and terrorism is not studied. Certain general content relating to respect for cultural diversity and the prevention of violence is present to a lesser extent. In this context, curricula should be aligned with good practise and recommendations (United Nations Educational, Scientific and Cultural Organization, 2016) regarding the role of education as a significant factor in the prevention of violent extremism and terrorism. There is a social need, but these topics have not received sufficient attention. During this phase of education, young people do not even acquire the elementary knowledge about these phenomena, and they are neither prepared to understand the events in their environment nor to recognize threats and know how to properly handle the crisis and protect themselves and others.

The second perspective on looking at the role of education in the context of radicalization, violent extremism and terrorism refers to higher education. Those holding a first-cycle degree find employment in the public or private sector. The education attained during undergraduate study is applied in practice with the assumption of further professional development. The rhetorical question is whether the existing curricula within various courses of study are sufficient to prepare them for prospective work roles. Opposition to radicalization, violent extremism, and terrorism does not exclusively fall under the domain of employees in law enforcement, intelligence or criminal justice agencies, but covers a much broader range of activities in society. The analysis of study programs revealed that this problem, to which the largest number of teaching hours is devoted, is studied at the Faculty of Security Studies, University of Banja Luka. The curriculum used by this Faculty envisages one course on terrorism studies, which is at the same time the only course exclusively dealing with the topic terrorism at the bachelor's level at both public universities in the Republika Srpska. In a particular segment, the topics related to terrorism are taught within other courses at this Faculty. Such an approach is understandable because this institution of higher education educates personnel to work in the security sector. The number of teaching hours is significantly higher in regard to the program taught at the College of Internal Affairs, whose legal successor is the Faculty of Security Studies. These are positive trends in higher education regarding the topics of radicalization, violent extremism, and terrorism.

The institutions of higher education that include a small number of teaching hours devoted to this topic within different curricula are law faculties at both public universities in the Republika Srpska. The number of teaching hours devoted to these topics is not sufficient to provide fundamentals of radicalization, violent extremism, and terrorism, particularly because a number of law school graduates find employment in police and security agencies. Within other study programs, the topic of terrorism is partially studied, within other courses, as one teaching unit only. The name of th course is International Relations within the study program Journalism at the University of East Sarajevo. There is a justifiable need that prospecive journalists have a general 34 knowledge of terrorism and the role of the media, be it traditional or social networks, which are extensively used for propaganda and to radicalize and recruit supporters. In practice, the media is also used by government institutions to gain public support for counter-terrorism measures (Nacos B., 2016). Further, within the study program Political Science and International Relations at the University of East Sarajevo, the topic of extremism and terrorism is studied as 
one unit within the course EU and BiH's foreign policy, while terrorism is studied as one unit within the Contemporary Political Systems course of the study program Sociology.

Following the September 11, 2001 terrorist attacks on the United States, a large number of universities worldwide introduced new courses (Silke, 2004) addressing terrorism from an interdisciplinary perspective. Additionally, research centers were set up at universities to deal exclusively with the phenomenon of terrorism. Considering the current state of higher education at public universities, these trends have not affected the education system and the topics in the field of terrorism studies remained peripheral within the Republika Srpska educational policy.

\section{CONCLUSION}

This paper sought to answer the questions about the extent to which the topics of radicalization, violent extremism and terrorism are studied in the public education system in the Republika Srpska, and whether the existing education system is adapted to the needs of society and the security environment.

Although the topics of extremism and radicalization are significantly present in public discourse, especially in the media, politics, police agencies and the judiciary in the Republika Srpska and entire BiH, their representation in the education system is extremely low. In this context, primary and secondary education along with the first cycle of higher education at public universities were analyzed. The research findings indicated that the primary and secondary education curricula do not contain topics on radicalization, violent extremism, and terrorism. Regarding higher education, the representation of these topics as a whole is insufficient with the exception of the Faculty of Security Studies, University of Banja Luka. In higher education, there is a lack of courses in the area of terrorism within many study programs. The phenomenon of terrorism is studied only within a number of study programs, with a minimum number of teaching hours. Terrorism is not only of particular interest to professionals in the security sector or criminal justice agencies, but it also has a much broader social and academic (multidisciplinary) context.

The analysis of the current state demonstrated that the answer to the second research question should be provided, that is to say, whether the existing curricula are adapted to the social needs and the security environment in which the Republika Srpska and the whole country of Bosnia and Herzegovina are situated. Looking at the levels of education analyzed, it can be concluded that the curricula do not properly prepare young people to understand terrorism and related phenomena. Taking into account the fact that the issue of radicalization in $\mathrm{BiH}$ is an important security issue, including the return of warriors who fought on the side of the terrorist organization ISIL and the terrorist attacks carried out in $\mathrm{BiH}$ - justification for studying terrorism at all levels of education in the Republika Srpska is not questionable. The prevention of radicalization, violent extremism, and terrorism through the system of education is a significant social resource that has not been sufficiently utilized.

Based on the research findings, the following recommendations are presented: It would be a good idea to introduce the subject Security Culture in 
primary and secondary education, and within this subject to pay special attention to the topics of radicalization, violent extremism, and terrorism, with an emphasis on the prevention and vulnerability of young people when being recruited to join radical movements and terrorist organizations.

In regard to higher education, the analysis of curricula and study programs at public universities is recommended, and justification for introducing (or the need to introduce) new subjects (compulsory or elective) which would address the mentioned topic from the perspective of different scientific disciplines should be considered.

\section{REFERENCES}

Altran, S., Axelrod, R., Davis, R., \& Fischhof, B. (2017). Challenges in Researching Terrorism from the Field. Science, 355 (6323), 352-354.

Азиновић, В. (2012). Увод у студије тероризма. Сарајево: Факултет политичких наука Универзитета у Сарајеву.

Азиновић, В., и Јусић, М. (2019). Нови зов рата у Сирији и босанскохерцеговачки контигент страних бораца. Сарајево: Атланска иницијатива.

Dongen, T. v. (2018). 130+(Counter-) Terrorism Research Centers-an Inventory. Perspectives on Terrorism, 12 (2), 86-124.

Факултет безбједносних наука. (2019, March 24). Укратко о факултету. Retrieved from https://fbn.unibl.org/ukratko-o-fakultetu/

Факултет безбједносних наука. (2019). Студијски програм Безбједност и криминалистика 2017/18. Retrieved from 10.3.2019. https://fbn.unibl.org/ studijski-program-bezbjednost-i-kriminalistika/

Филозофски факултет. (2019, Мау 24). Студијски програм Новинарство. Retrieved from http://www.ff.ues.rs.ba/files/docs/users/Urednik/Novinarstvosilabusi/medjunarodni-odnosi.pdf

Филозофски факултет. (2019, Мау 22). Студијски програм Политикологија и међународни односи. Retrieved from http://www.ff.ues.rs.ba/files/docs/ users/Urednik/Politikologija-silabusi/eu-i-spoljna-politika-bih.pdf

Филозофски факултет. (2019, Мау 22). Студијски програм Социологија. Retrieved from http://www.ff.ues.rs.ba/files/docs/users/Urednik/Sociologija-silabusi/ savremeni-politicki-sistemi-sociologija.pdf

Gordon, A. (2004a). Applying Analytical Methods to Study Terrorism. International Studies Perspectives, 3 (8), 287-302.

Gordon, A. (2004b). Terrorism and Knowledge Growth: A Databases and Internet Analysis. In: Andrew Silke (Ed.). Research on Terrorism : Trends, Achievements \& Failures. London: Routledge, 104-118.

Hague, M. S. (2002). Government responses to terrorism: Critical views of their impacts on people and public administration. Public Administration Review, 62, 170-180. 
Jackson, R. (2012). The Study of Terrorism 10 Years After 9/11: Successes, Issues, Challenges. Uluslararası iliş̧kiler, 32 (8), 1-16.

Mahoney, C. (2017). More Data, New Problems: Audiences, Ahistoricity, and Selection Bias in Terrorism and Insurgency Research. International Studies Review, 20 (4), 589-614.

Мијалковић, С. (2014). Методологија пројектовања програма стручног усавршавања просветних радника из области безбедности. Безбједностполищија-грађани, 1-2, 47-61.

Mušić, S. (2016). Uloga obrazovanja u prevenciji nasilnog ekstremizma i radikalizma. Changing reality through education (str. 1-9). Mostar: Džemal Bijedić.

Nacos, B. (2016). Mass-mediated terrorism: Mainstream and digital media in terrorism and counterterrorism. Maryland: Rowman \& Littlefield.

Nacos, B. L. (2016). Terrorist Propaganda and the Mainstream Media. In: N. B. L, Terrorism and Counterterrorism (pp. 26). New York: Routledge.

Наставни план и програм Високе школе унутрашњих послова (2012). Бањалука: Висока школа унутрашњих послова.

Правни факултет. (2019, March 22). Кривично право. Retrieved from https:// pf.unibl.org/krivicno-pravo/

Правни факултет. (2019, March 22). Криминологија са пенологијом. Retrieved from https://pf.unibl.org/kriminologija-sa-penologijom/

Правни факултет. (2019, March 22). Организовани криминалитет. Retrieved from https://pf.unibl.org/organizovani-kriminalitet/

Правни факултет. (2019, Мау 10). Студијски програми - силабуси за први циклус cmyduja. Retrieved from https://www.pravni.ues.rs.ba/Download/NastavniPlan.pdf

Prislan, K., Černigoj, A., \& Lobnikar, B. (2018). Preventing radicalisation in the Western Balkans: The role of the police using a multi-stakeholder approach. Ravija za kriminalistiko in kriminologijo 69 (4), 257-268.

Ragazzi, F. (2017). Countering terrorism and radicalisation: Securitising social policy? Critical Social Policy, 37 (2), 163-179.

Reid, E. (1997). Evolution of a Body of Knowledge: An Analysis of Terrorism Research. Information Processing \& Management, 1 (33), 91-106.

Републички педагошки завод [РПЗ]. (2019). Наставни план и програм за основно образовање и васпитање у Републици Српској 2014. Retrieved from 25.5.2019. https://www.rpz-rs.org/sajt/doc/file/web_portal/05/5.2/ Nastavni\%20plan\%20i\%20program\%20za\%20osnovnu\%20skolu.pdf

Републички педагошки завод [РП3]. (2019, March 22). Наставни план и програм за средње образовање и васпитање. Retrieved from https://www.rpz-rs. org/22/rpz rs/Za/srednje/obrazovanje/i/vaspitanje\#.XjXPH2hKjlU

Schuurman, B. (2018). Research on Terrorism, 2007-2016: A Review of Data, Methods, and Authorship. Terrorism and Political Violence, 1 (30), 1-16. 
Sheehan, I. S. (2012). Mapping Contemporary Terrorism Courses at Top-Ranked National Universities and Liberal Arts Colleges in the United States. Perspectives on Terrorism, 6 (2), 19-50.

Silke, A. (2001). The Devil you Know: Continuing Problems with Research on Terrorism. Terrorism and political Violence, 4 (13), 1-14.

Silke, A. (2004). An introduction to terrorism research. Research on terrorism: trends, achievements and failures (pp. 1-29). New York: Routledge.

Стајић, Љ., Мијалковић, С., \& Станаревић, С. (2006). Безбедносна култура младих - како живети безбедно. Београд: Драганић.

Станаревић, С., \& Бодин, М. (2014). Безбедносна култура као друштвени ресурс националне безбедности. Војно дело, 66, 84-104.

Thomas, P. (2016). Youth, terrorism and education: Britain's Prevent programme. International Journal of Life-Long Education, special issue: 'Youth, Social Crisis and Learning, 2 (35), 171-187.

UNDOC. (2017). Handbook on Children Recruited and Exploited by Terrorist and Violent Extremist Groups: The Role of the Justice System. Vienna: United Nationas.

United Nations Educational, Scientific and Cultural Organization. (2016). Teacher's Guide on the Prevention of VIOLENT EXTREMISM . Paris: UNESCO.

Универзитет у Бањој Луци. (2019, May 22). О Универзитеmy. Retrieved from http://www.unibl.org/sr/univerzitet/o-univerzitetu

Универзитет у Источном Сарајеву. (2019, Мау 10). О Универзитету. Retrieved from https://www.ues.rs.ba/o-univerzitetu/

Закон о високом образовању Републике Српске - ЗоВО, Службени Гласник РС, број 73/10; 104/11; 84/12; 108/13; 44/15; 90/16 и 31/18).

Paper received on: 15. 12. 2019.

Paper acceptted for publishing on: 13. 01. 2020. 


\title{
ПРЕВЕНЦИЈА РАДИКАЛИЗАЦИЈЕ, НАСИЛНОГ ЕКСТРЕМИЗМА И ТЕРОРИЗМА КРОЗ СИСТЕМ ОБРАЗОВАҢА У РЕПУБЛИЦИ СРПСКОЈ
}

Оригинални научни рад

\begin{tabular}{|l|l|l|}
\hline DOI 10.5937/zurbezkrim1902025S & COBISS.RS-ID 8628760 & УДК 37.014.5:321.64]:323.28 \\
\hline
\end{tabular}

\author{
Милица Сикимић ${ }^{1}$ \\ Факултет безбједносних наука, Универзитет у Бањој Луци \\ Велибор Лалић \\ Факултет безбједносних наука, Универзитет у Бањој Луци \\ Предраг Ћеранић \\ Факултет безбједносних наука, Универзитет у Бањој Луци
}

Апстракт: Образовање представља извор сазнања о социјалним појавама и процесима, те у превенцији друштвено штетних понашања има значајну улогу. У овом раду анализирано је у којој су мјери заступљени образовни садржаји на тему радикализације, насилног екстремизма и тероризма у основном, средњем и високом образовању (на јавним универзитетима) и колико су предвиђене наставне теме прилагођене актуелном безбједносном амбијенту. Према кључним ријечима „радикализација“, „насилни екстремизам“ и „тероризам“ анализирани су наставни планови и програми за сва три нивоа образовања у Републици Српској и након тога извршена је квантитативна и квалитативна анализа. Резултати истраживања су показали да у основном и средњем образовању нема наставних тема о радикализацији, насилном екстремизму и тероризму. Што се тиче високог образовања, евидентан је недостатак курсева из ове области на различитим студијским програмима. Теме из студија тероризма углавном су остале на маргинама политике образовања у Републици Српској.

Кључне ријечи: радикализација, насилни екстремизам, тероризам, образовање, превенција.

\section{УВОД}

Поредтогаштосеполиција,службебезбједностииправосуђенепосредно баве питањима радикализације, насилног екстремизма и тероризма, ове појаве би требало да буду предмет интересовања цјелокупног друштва. Репресивно дјеловање у њиховом сузбијању је незаобилазно. Међутим, репресивне мјере уколико нису праћене превентивним дјеловањем не могу дати дугорочне и одрживе резултате (Thomas, 2016). Систем образовања може да има врло важну улогу у превенцији ових друштвено деструктивних појава. Млади су посебно рањива категорија за разне облике манипулације

1 Аутор за кореспонденцију: Милица Сикимић, МА, асистент на Факултету безбједносних наука, Универзитет у Бањој Луци. E-mail: milica.sikimic@fbn.unibl.org 
и индоктринације, посебно путем савремених информационих технологија. Ширење екстремистичких идеја и радикализација путем интернета је у великој мјери распрострањена појава. Према подацима Уједињених нација у посљедњих неколико година у порасту је број дјеце која су регрутована и експлоатисана од стране терористичких организација. Превенција регрутовања дјеце је свеобухватан процес који захтијева интеграцију више приступа и знања из различитих области (UNDOC, 2017).

Полицијски службеници често нису у прилици да се активније укључе у превентивне активности, првенствено због преоптерећености оперативним пословима. Ту се отвара значајан простор за систем образовања, гдје би млади људи кроз образовне процесе стекли основна знања о радикализацији, насилном екстремизму и тероризму. Едукација може помоћи младима да развију интерперсоналне вјештине мирног приступа промјенама и неслагању са другима, да испитују легитимитет и оправданост, као и ставове које прокламују терористичке организације, а може помоћи и развијању њиховог отпора према насилном дјеловању. ${ }^{2}$

Образовање из области безбједности представља велики изазов за свако друштво. У том смислу, кључна је важност да наставне активности изводи квалитетан кадар на свим нивоима образовања. С тим у вези, намеће се потреба за атрактивним и плановима и програмима који имају јасне образовне циљеве и друштвену оправданост (Мијалковић, 2014).

Превенција екстремизма и тероризма има велику важност у сваком друштву, а посебно у Босни и Херцеговини - постконфликтној земљи која се у значајној мјери суочава са овим проблемима (Азиновић, 2012). Исламски фундаментализам и извршени терористички акти у Босни и Херцеговини су друштвена стварност, колико год се овај проблем покушавао минимизирати и релативизовати од стране појединих политичких елита и дијела јавности у земљи.

Прегледом литературе уочени су радови у којима се третитирају онтолошка, епистемолошка и методолошка питања студија тероризма (Reid, 1997; Silke, The Devil you Know: Continuing Problems with Research on Terrorism, 2001; Gordon, Applying Analytical Methods to Study Terrorism, 2004a; Jackson, 2012; Gordon, Terrorism and Knowledge Growth: A Databases and Internet Analysis, 2004b; (Sheehan, 2012; Mahoney, 2017; Altran, Axelrod, Davis, \& Fischhof, 2017; Schuurman, 2018). Ти аспекти се односе на стварање знања о тероризму, док су питања у вези са ширењем тог знања у образовној дјелатности, што је врло битан аспект значајно запостављена3 (Мушић, 2016; Мијалковић, 2014; Sheehan, 2012; Gordon, Applying Analytical Methods

\footnotetext{
2 Водич за наставнике о превенциији насилног екстремизма УНЕСКО савјетује да се са ученицима дискутује о локалним манифестацијама радикалних и екстремних увјерења, умјесто апстрактног приступа на свјетском нивоу. Конкретним примјерима из најближе околине младима се може омогућити да разумију повезаност између локалних и свјетских изазова, да буду свјесни стварних ризика и посљедица тероризма. У свему наведеном, наставник треба да буде модератор разговора и објективан према друштвеним, културним, етничким и другим разноликостима у локалном контексту и наравно, особа са предзнањима о насилном екстремизму и тероризму (UNESCO, 2016: 13-17).

3 Посебно ако узмемо чињеницу да се након терористичког напада на САД 11. септембра 2001. на већини универзитета уводе наставни предмети из тероризма из различитих научних дисциплина (Silke, 2004).
} 
to Study Terrorism, 2004a). Прегледом литературе нисмо идентификовали слична истраживања о заступљености тема која се односе на радикализацију, насилни екстремизам и тероризам у процесу образовања.

Ово истраживање је експлоративне природе тако да није било у могућности за упоређивање резултате овог истраживања са резултатима сличних истраживања у региону или шире. Циљ овог рада је да се утврди у којој су мјери у Републици Српској, заступљени образовни садржаји на тему радикализације, насилног екстремизма и тероризма у основном, средњем и високом образовању (на јавним универзитезима) и колико постојећи наставни садржаји одговарају потребама праксе.

У фокусу истраживања су два основна истраживачка питања: 1) у којој мјери се тематика радикализације, насилног екстремизма и тероризма изучава у систему јавног образовања у Републици Српској и 2) да ли су постојећи наставни планови и програми прилагођени друштвеним потребама и безбједносном амбијенту у коме се налазимо.

\section{МЕТОДОЛОГИЈА}

Извршена је анализа садржаја наставних планова и програма у јавним образовним установама у Републици Српској. Анализирани су планови и програми у основном, средњем и високом образовању. Министарство просвјете и културе Републике Српске, односно Републички педагошки завод утврђују наставне планове и програме за основно образовање и васпитање, као и средњошколско образовање у Републици Српској. Наставним плановима и програмима утврђени су наставни предмети, њихов распоред по разредима, годишњи и седмични број часова наставе, као и садржаји по којима ће се изводити настава (Републички педагошки завод, 2019). У Републици Српској високо образовање се спроводи у оквиру јавних и приватних високошколских установа које дјелатност обављају према различитим наставним плановима и програмима (Закон о високом образовању Републике Српске, члан 11-24, Сл. гласник РС број 73/10; $104 / 11 ; 84 / 12 ; 108 / 13 ; 44 / 15 ; 90 / 16$ и 31/18). Имајући у виду да је предмет рада заступљеност наставних садржаја о радикализацији, насилном екстремизму и тероризму, анализирани су наставни планови и програми два јавна универзитета у Републици Српској: Универзитет у Бањој Луци и Универзитет у Источном Сарајеву. Сви наставни планови и програми анализирани су на кључне ријечи радикализација, екстремизам и тероризам. Након идентификовања кључних ријечи извршена је квантитативна и квалитативна анализа наставних планова и програма. Поред наведеног анализирани су и садржаји који се посредно могу односити на превенцију насиља које има политичку, националну, етничку, расну или сличну конотацију. Анализом садржаја наставних планова и програма добијени су квантитативни показатељи, тј. фонд часова који се изводе у наставном процесу у основном, средњем и високом образовању као и квалитативни показатељи, тј. садржај наставних јединица које обрађују теме екстремизма и тероризма. 


\section{НАСТАВНИ ПЛАН И ПРОГРАМ ЗА ОСНОВНО И СРЕДЊЕ ОБРАЗОВАҢЕ И ВАСПИТАЬЕ У РЕПУБЛИЦИ СРПСКОЈ}

у Републици Српској, Републички педагошки завод ${ }^{4}$ надлежан је за доношење наставних планова и програма за основно и средње образовање и васпитање. Наставни планови садрже називе наставних предмета, наставне садржаје и фонд часова за извођење наставе (Републички педагошки завод, 2019).

Наставни план за основно образовање у Републици Српској предвића наставне предмете: Српски језик (језик бошњачког, односно, хрватског народа); Православна вјеронаука; први страни језик; други страни језик; Ликовна култура; Музичка култура; Природа и друштво; Познавање природе; Познавање друштва; Историја; Демократија и људска права; Географија; Физика; Математика; Биологија; Хемија; Техничко образовање; Основи информатике; Физичко васпитање; Моја околина; Говор, изражавање, стварање; Физичко васпитање, ритмика, музика; Васпитни рад у одјељенској заједници (Републички педагошки завод, 2019).

Анализом наставних планова уочено је да истима нису обухваћене теме које се директно односе на радикализацију, насилни екстремизам и тероризам. Међутим, одређени наставни саджаји обрађују теме које за циљ имају развој толеранције и уважавања културних различитости. Такви садржаји пронађени су у наставним плановима Православне вјеронауке и часовима одјељенске заједнице. ${ }^{5}$ Као примјер наводимо сегмент из плана наставног предмета Православна вјеронаука који се односи на циљеве предмета: „развијање осјећаја личне одговорности и самосвјесне обавезе, да би се могли правилно опредијелити према добру и злу као основним моралним категоријама; и „развијање правилног односа према породици и друштву, према људима који другачије живе, мисле и вјерују.“"Након спроведене наставе од ученика се очекује да „препозна разлику између добра и зла“ и „објасни важност чињења добрих дјела и избјегавања лоших" (Републички педагошки завод, 2019). Такође, у већини разреда на часовима одјељенске заједнице планирана наставна темаје превенција насиља у оквиру које ученици треба да препознају насилне облике понашања, различитости као повод за насилно понашање, те да развијају друштвено прихватљиве обрасце понашања према индивидуалним и групним различитостима (Републички педагошки завод, 2019).

Што се тиче средњошколског образовања у Републици Српској према подацима Републичког педагошког завода свршеним основцима је на располагању укупно 13 занимања и Гимназија са четири смјера (Републички педагошки завод, 2019). Анализом наставних садржаја нису утврђени они који директно или посредно третирају тематику радикализације, насилног екстремизма или тероризма.

\footnotetext{
4 Републички педагошки завод је управна организација у саставу Министарства просвјете и културе.

5 у Републици Српској у школама се изводи и настава исламске и католичке вјеронауке, али наставни планови и програми нису доступни на сајту Републичког педагошког завода Републике Српске, тако да ти планови нису анализирани. То не искључује чињеницу да се у оквиру тих предмета ученици уче универзалним виједностима толераниције и уважавања културних различитости.
} 


\section{СТУДИЈСКИ ПЛАНОВИ И ПРОГРАМИ ЗА ПРВИ ЦИКЛУС СТУДИЈА НА ЈАВНИМ УНИВЕРЗИТЕТИМА У РЕПУБЛИЦИ СРПСКОЈ}

У Републици Српској постоје два јавна универзитета: Универзитет у Бањој Луци и Универзитет у Источном Сарајеву, чији су наставни планови и програми првог циклуса студија анализирани у сврху овог истраживања.

\section{Универзитеиеи у Бањој Луци}

Водећа високошколска образовна институција у Републици Српској, а друга по величини у БиХ, јесте Универзитет у Бањој Луци који има 17 факултета са 58 студијских програма првог циклуса, 65 студијских програма другог циклуса и 9 студијских програма трећег циклуса студија (Универзитет у Бањој Луци, 2019). Анализирани су студијски програми првог циклуса на Правном факултету и Факултету безбједносних наука, односно факултетима на чијим веб сајтовима су идентификовани наставни садржаји који се могу довести у везу са радикализацијом, насилним екстремизмом и тероризмом.

У наставном плану и програму Правног факултета Универзитета у Бањој Луци пронађена су три предмета у оквиру којих се у одређеном сегменту обрађују наведени садржаји. То је Кривично право, Криминологија са пенологијом и Организовани криминалитет. На другој години студија, тачније у трећем семестру, обавезан предмет је Кривично право са наставном јединицом „Кривична дјела тероризма“ (Правни факултет, 2019). Криминологија са пенологијом је обавезан предмет на трећој години студија, а студенти треба да стекну знања „из области криминалне етиологије и феноменологије, као и из области пенологије. У садржају предмета Криминологија са пенологијом не налазимо термин „тероризам“, међутим, неке од предвиђених наставних јединица баве се етиологијом криминалитета, посебно његовим економским, политичким и идеолошким чиниоцима (Правни факултет, 2019). На четвртој години студија студенти могу да се опредијеле за изборни предмет Организовани криминалитет у којем налазимо наставну тему „утврђивање начина прања новца у ланцу организованог криминала и финансирања терористичких активности“, а тражени ниво знања треба да омогући студентима боље разумијевање организованог криминалитета и савремених безбједносних изазова, ризика и пријетњи (Правни факултет, 2019).

Факултетбезбједноснихнауканастаоје 2017.године, трансформацијом Високе школе унутрашњих послова Бања Лука, која је дјеловала у оквиру Министарства унутрашњих послова Републике Српске. Тренутно се изводи настава по старом и новом студијском програму Безбједност и криминалистика, у оквиру којег постоје два усмјерења: полицијски и криминалистички, а студенти се опредјељују након треће године студија. Стари студијски програм Високе школе унутрашњих послова похађају генерације студената које су уписане прије школске 2017/18. године, док нови студијски програм похађају генерације уписане након школске 2017/18 (Укратко о факултету, 2019). 
На студијском програму Високе школе унутрашњих послова студенти су се по први пут сусретали са појмом тероризам на другој години студија, у оквиру обавезног наставног предмета Криминалистичка методика. Наставна јединица наслова „Тероризам - међународни тероризам“ обрађивана је на три наставна часа предавања и два часа вјежби, на којима су усвајана знања о појму, карактеристикама, врстама и појавним облицима тероризма, средствима, начинима извршења и сазнања о извршеним кривичним дјелима тероризма, откривању и хватању терористе, као и о карактеристикама и појавним облицима међународног тероризма (Висока школа унутрашњих послова, 2012). На трећој години студија обавезни наставни предмет је Организовани криминалитет са предвиђеном наставном јединицом „однос организованог криминалитета и тероризма“, такође фонда 3+2 часова (Висока школа унутрашњих послова, 2012), док су у седмом семестру Криминалистичког смјера ${ }^{6}$ на изборном предмету Високотехнолошки криминалитет, четири часа предвиђена за тему сајбер тероризам, у овиру чега се обрађују теме појмовног одређења сајбер тероризма, његових карактеристика, профила сајбер терориста, као и начини супротстављања овом виду тероризма (Висока школа унутрашњих послова, 2012).

У плану и програму полицијског усмјерења налазе се три наставна предмета која се баве тероризмом, али ниједан од тих предмета нема статус обавезног предмета. Силабус предмета Обавјештајнобезбједносна дјелатност и службе предвића укупно осам часова (четири предавања и четири вјежбе) на тему екстремизма и тероризма, појма и врста унутрашњег екстремизма и тероризма, екстремне политичке и терористичке организације, међународног тероризма, те облицима испољавања екстремистичког и терористичког дјеловања. У оквиру наставне теме још се обрађује и тоталитаризам, екстремни национализам и сепаратизам, илегално организовање и бандитизам, завјереничкопревратничко дјеловање, појединачни акти насиља, изазивање грађанског рата и иностране интервенције. Друге наставне јединице које се могу повезати са предметом овог рада су идеолошко-политичка индоктринација и вјерски фанатизам (Висока школа унутрашњих послова, 2012). Из изборног предмета Систем безбједности и заштите студенти имају прилику да се упознају са појмом тероризма, карактеристикама и манифестовању тероризма, као и о структурама терористичких организација у трајању од укупно четири наставна часа (Висока школа унутрашњих послова, 2012). Студенти су такође имали могућност опредјељења за похађање наставе из изборног предмета Тероризам укупног фонда од 60 часова (30 предавања и 30 вјежбе), а као циљ изучавања предмета наводи се стицање основних знања о глобализацији и тероризму и његовој примјени; форми и садржини организовања терористичких организација, новим облицима тероризма и борбе против тероризма (Висока школа унутрашњих послова, 2012).

На студијском програму Безбједност и криминалистика 2017/18 30 наставу похађају сви студенти који су први пут уписани у прву годину студија у академској 2017/18 години и након тога. Наставни план и програм је измијењен са новим, актуелним садржајима у складу са промјенама у безбједносном окружењу. Савладавање градива из појединих (обавезних)

\footnotetext{
6 Приликом уписа у четврту годину студија студенти су имали могућност опредјељења између два смјера: Криминалистички смјер и Полицијски смјер.
} 
наставних предмета захтијева знање о тероризму, а фонд часова на којима је предвићено учење о тероризму је значајно повећан. Већ у првом семестру, на наставном предмету Основе безбједносних наука укупно је 6 наставних часова предвиђених за упознавање студената са тероризмом као безбједносном пријетњом на националном и међународном нивоу (Факултет безбједносних наука, 2019). У наставном плану предмета Дефендологија, у оквиру којег се изучавају савремене студије безбједности, на тему тероризма као пријетње политичком сектору безбједности предвиђено је укупно 6 часова (4 предавања и 2 вјежбе) (Факултет безбједносних наука, 2019). Значајна новина новог студијског плана и програма је што су предмети Тероризам и Обавјештајно-безбједносна дјелатност и службе предвиђени као обавезни (Факултет безбједносних наука, 2019). Обавезне предмете Глобална безбједност и Заштита критичне инфраструктуре на којима ће бити ријечи о тероризму овом приликом нису анализирани из разлога што још увијек нису активни по новом студијском програму и могуће су измјене достављених силабуса, а на претходном студијском програму из 2014/15 нису постојали.

Прегледом фонда часова долази се до резултата да је на Правном факултету минимално 13, а максимално 17 часова (кроз изборне предмете) посвећено тероризму. На Факултету безбједносних наука по плану и програму од 2014/15 године имамо број од минимално 10, а максимално 82 , док студенти који студирају по плану и програму од 2017/18 године морају обрадити 110 часова посвећених наставним темама о различитим аспектима тероризма.

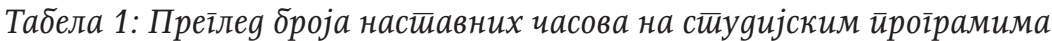
Универзитетйа у Бањој Луии на којима се іовори о раяикализаиији, насилном ексииремизму и иеероризму

\begin{tabular}{|c|c|c|c|}
\hline \multicolumn{4}{|c|}{ УНИВЕРЗИТЕТ У БАЮОЈ ЛУЦИ } \\
\hline \multicolumn{4}{|l|}{ Правни Факултет } \\
\hline Назив предмета & $\begin{array}{c}\text { Статус } \\
\text { предмета }\end{array}$ & \multicolumn{2}{|c|}{$\begin{array}{c}\text { Фонд часова на којима се говори } \\
\text { о тероризму }\end{array}$} \\
\hline Кривично право & Обавезан & \multicolumn{2}{|c|}{7} \\
\hline $\begin{array}{l}\text { Криминиологија са } \\
\text { пенологијом }\end{array}$ & Обавезан & \multicolumn{2}{|c|}{6} \\
\hline Организовани криминалитет & Изборни & \multicolumn{2}{|c|}{4} \\
\hline \multirow{2}{*}{\multicolumn{2}{|c|}{$\begin{array}{l}\text { Укупан фонд часова на студијском програму } \\
\text { на којима се говори о тероризму }\end{array}$}} & Минимално & Максимално \\
\hline & & 13 & 13 \\
\hline \multicolumn{4}{|l|}{ Факултет безбједносних наука } \\
\hline \multicolumn{4}{|c|}{ Дийломирани ирравник унуйрашних иоослова } \\
\hline Назив предмета & $\begin{array}{c}\text { Статус } \\
\text { предмета }\end{array}$ & \multicolumn{2}{|c|}{$\begin{array}{c}\text { Фонд часова на којима се говори } \\
\text { о тероризму }\end{array}$} \\
\hline Криминалистичка методика & Обавезан & \multicolumn{2}{|c|}{5} \\
\hline
\end{tabular}




\begin{tabular}{|c|c|c|c|}
\hline Организовани криминалитет & Обавезан & \multicolumn{2}{|c|}{5} \\
\hline $\begin{array}{l}\text { Високотехнолошки } \\
\text { криминалитет }\end{array}$ & Изборни & \multicolumn{2}{|c|}{4} \\
\hline $\begin{array}{l}\text { Обавјештајно-безбједносна } \\
\text { дјелатност и службе }\end{array}$ & Изборни & \multicolumn{2}{|c|}{8} \\
\hline Систем безбједности и заштите & Изборни & \multicolumn{2}{|c|}{4} \\
\hline Тероризам & Изборни & \multicolumn{2}{|c|}{60} \\
\hline \multirow{2}{*}{\multicolumn{2}{|c|}{$\begin{array}{l}\text { Укупан фонд часова на студијском програму } \\
\text { на којима се говори о тероризму }\end{array}$}} & Минимално & Максимално \\
\hline & & 10 & 80 \\
\hline \multicolumn{4}{|c|}{ Дийломирани ирравник безбјеяносиии и криминалистике } \\
\hline Основе безбједносних наука & Обавезан & \multicolumn{2}{|c|}{6} \\
\hline Дефендологија & Обавезан & \multicolumn{2}{|c|}{6} \\
\hline Тероризам & Обавезан & \multicolumn{2}{|c|}{90} \\
\hline $\begin{array}{l}\text { Обавјештајно-безбједносна } \\
\text { дјелатност и службе }\end{array}$ & Обавезан & \multicolumn{2}{|c|}{8} \\
\hline \multicolumn{2}{|c|}{$\begin{array}{l}\text { Укупан фонд часова на студијском програму } \\
\text { са наставним темама о различитим аспектима } \\
\text { тероризма }\end{array}$} & \multicolumn{2}{|c|}{$\begin{array}{c}\text { Минимално/максимално } \\
110\end{array}$} \\
\hline
\end{tabular}

Извор: обрада аутора

\section{Универзийей у Исйочном Сарајеву}

Универзитет у Источном Сарајеву у свом саставу има 17 организационих јединица са 56 студијских програма на првом, 48 на другом и 11 на трећем циклусу студија (Универзитет у Источном Сарајеву, 2019). Иако студијски програми првог циклуса на правним факултетима јавних универзитета у Републици Српској нису идентични, на предметима Кривично право и Криминологија са пенологијом Правног факултета у Источном Сарајеву налазимо исте наставне теме као и претходно описане на истим предметима на Правном факултету у Бањој Луци, те их нећемо поново описивати. Разлика је што на Правном факултету у Источном Сарајеву Организовани криминалитет није предвиђен као наставни предмет (Правни факултет, 2019).

На више студијских програма Филозофског факултета идентификовано је неколико предмета са предвиђеним наставним јединицима о насилном екстремизму и тероризму. На студијском програму Новинарство, у четвртој години обавезан предмет Међународни односи предвиђа укупно $5(3+2)$ часова

32 на тему „Тероризам и међународни односи“ (Филозофски факултет, 2019). Изборни предмет на студијском програму Политикологија и међународни односи - међународни смјер, на наставном предмету ЕУ и спољна политика БиХ предвиђено је 5 часова $(3+2)$ за обраду наставне јединице „Изазови екстремизма, тероризма у ЕУ и БиХ““ (Филозофски факултет, 2019). Студијски програм Социологија у оквиру предмета Савремни политички системи обрађује 
тему „Политика ЕУ у области слободе, безбједности и борбе против тероризма“ (Филозофски факултет, 2019).

Други садржаји на тему радикализације, насилног екстремизма и тероризма нису идентификовани.

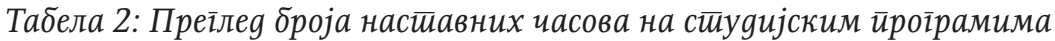
Универзииетиа у Исйочном Сарајеву на којима се іовори о насилном ексииремизму и иеероризму

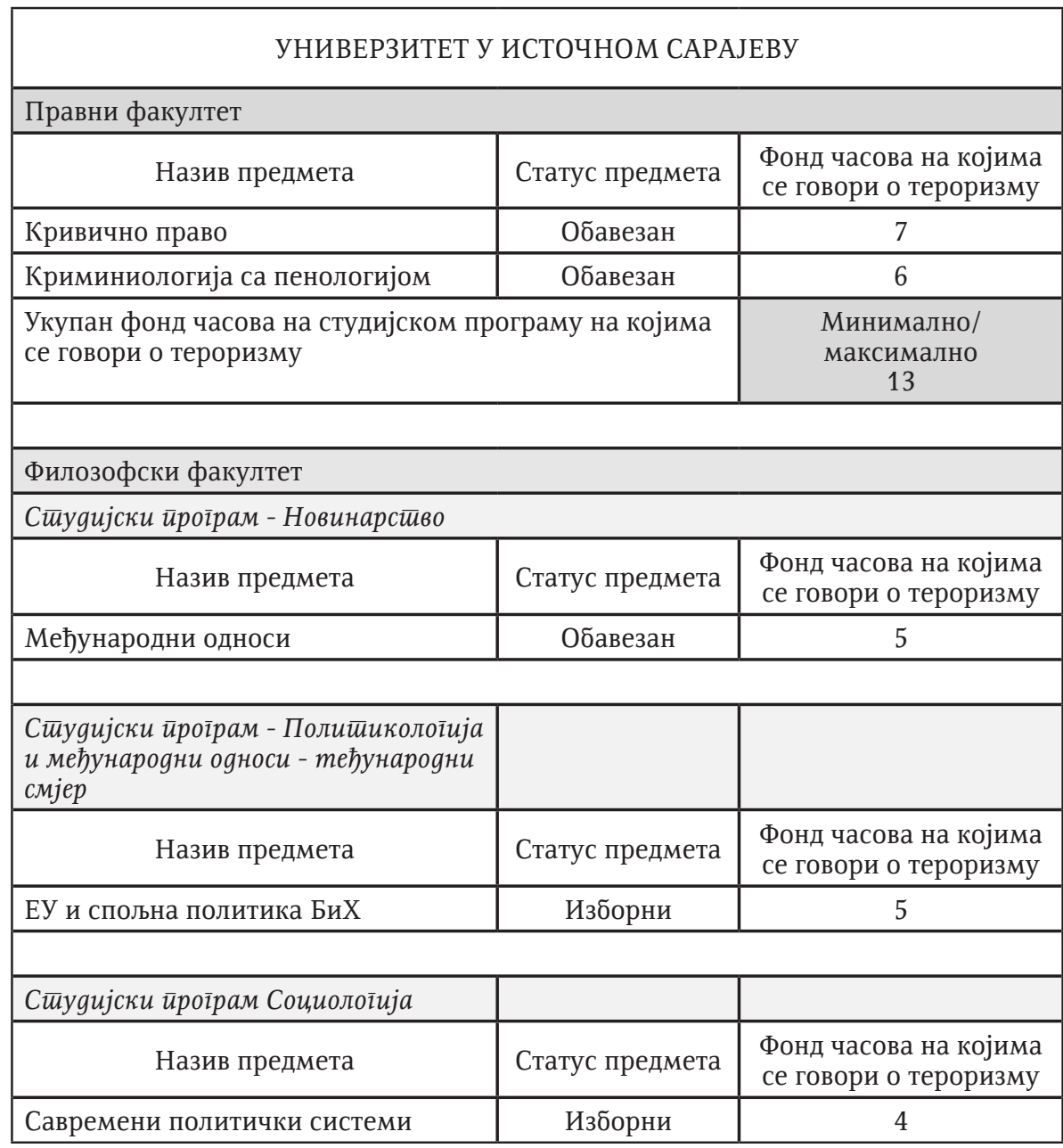

Извор: обрада аутора

Прегледом фонда часова добијени резултати су: 13 наставних часова на Правном факултету и укупно 14 часова на три студијска програма Филозофског факултета Универзитета у Источном Сарајеву. 


\section{ДИСКУСИЈА}

Да ли јавно образовање у Републици Српској адекватно оспособљава младе људе да разумију сваремено друштвено окружење и да препознају опасности радикализације, насилног екстремизма и тероризма? Босна и Херцеговина, укључујући и неке друге дијелове Западног Балкана (Europol, 2017 ) суочава се са проблемом радикалног ислама. Тај проблем у Босни и Херцеговини значајно је изражен (Азиновић \& Јусић, Нови зов рата у Сирији и босанскохерцеговачки контигент страних бораца, 2019; Prislan, Černigoj, \& Lobnikar, 2018) и заслужује пажњу практичара, истраживача и јавности у цјелини. Актуелност ове проблематике представља императив да се у политици образовања у Републици Српској нађе адекватно мјесто за едукацију нових генерација на свим нивоима образовања.

Улога образовања, у вези са наставним садржајима који третирају тематику радикализације, насилног екстремизма и тероризма, у Републици Српској може се посматрати из двије основне перспективе. Прва се односи на основно и средње образовање, током којег би ученици требало да се упознају са основним карактеристикама ових појава и пријетњама које оне генеришу. Она би требало да имају за циљ подизање безбједносне културе младих на виши ниво, како би млади стекли адекватна знања да препознају пријетње и да на њих адекватно реагују (Стајић, Мијалковић \& Станаревић, 2006; Станаревић \& Бодин, 2014). Овај сегмент образовања ученика има примарну важност. Са друге стране, млади људи током школовања усвајају вриједности уважавања културних различитости и рјешавања спорова, било на индивидуалном или на нивоу друштвених група - искључиво на миран начин, дијалогом и толеранцијом.

У контексту високог образовања, тематика радикализације, насилног екстремизма и тероризма има велики значај за припрему будућих дипломаца да у свом професионалном раду у довољној мјери буду обучени да се носе са професионалним изазовима у све више несигурном друштвеном окружењу. Ова знања нису искључиво намијењена професионалним припадницима сектора безбједности или правосудних органа, већ и запосленим у другим дјелатностима, попут медија (Nacos, 2016), центара за социјални рад (Ragazzi, 2017), јавној управи (Hague, 2002), истраживачким центрима (Dongen, 2018 ) итд. Спектар дјелатности је широк и обухвата све сегменте друштвеног живота.

Сада се освртом на резултате истраживања сагледа у ком обиму се изучавају наведени садржаји и у којој мјери одговарају потребама друштва. Прво је дат осврт на наставне планове и програме у основном и средњем образовању. Резултати истраживања су показали да се садржаји о радикализацији, насилном екстремизму и тероризму не изучавају. Одређени општи садржаји који се односе на поштовање културних различитости и превенцију насиља су заступљени, у мањем обиму. У том контексту наставни планови и програми би требало да буду усаглашени са добрим праксама и препорукама (United Nations Educational, Scientific and Cultural Organization, 2016) о улози образовања као значајног чиниоца за спречавање насилног екстремизма и тероризма. Друштвена потреба постоји, али овим темама није посвећена адекватна пажња. Млади током ове фазе образовања не стичу чак ни елементарна знања о овим феноменима, и нису припремљени 
да разумију дешавања у свом окружењу нити да препознају пријетње и знају како треба правилно поступити у кризној ситацији и заштитити себе и друге.

Друга перспектива посматрања улоге образовања у контексту радикализације, насилног екстремизма и тероризма односи се на високо образовање. Свршени студенти првог циклуса студија запошљавају се у јавном или приватом сектору. Стечено обазовање током студија примјењују у пракси уз претпоставку даљњег стручног усавршавања. Реторичко је питање да ли су постојећи наставни садржаји на различитим програмима довољни да их припреме за будуће радне улоге. Супротстављање радикализацији, насилном екстремизму и тероризму није искључиви домен запослених у полицијским агенцијама, обавјештајним службама или правосуђу, већ обухвата много шири спектар дјелатности у друштву. Анализом студијских програма утврђено је да се ова проблематика са највећим фондом часова изучава на Факултету безбједносних наука Универзитета у Бањој Луци. На том факултету планом и програмом предвићен је један наставни предмет из студија тероризма, што је уједно једини наставни предмет на оба јавна универзитета у Републици Српској на првом циклусу студија који искључиво третира тематику тероризма. У одређеном сегменту на овом факултету теме из тероризма изучавају се у оквиру других наставних предмета. Такав приступ је разумљив јер се на тој високообразовној установи школују кадрови за рад у сектору безбједности. Фонд часова знатно је већи у односу на програм Високе школе унутрашњих послова чији је правни насљедник Факултет безбједносних наука. То су позитивни трендови у високом образовању када је ријеч о темама из радикализације, насилног екстремизма и тероризма.

Наредне високошколске институције које у наставним плановима и програмима садрже мањи фонд часова на ову тему, у оквиру различитих наставних предмета, јесу правни факултети на оба јавна универзитета у Републици Српској. Фонд часова гдје се експлицитно изучавају наведене теме је минималан и недовољан како би се добиле основе из ове тематике. Посебно што одређени број дипломаца правног факултета заснива радни однос у полицијским и безбједносним агенцијама. На другим студијским програмима тематика тероризма изучава се парцијално, у оквиру других предмета, и само као једна наставна јединица. Ради се о предмету Међународни односи на студијском програму Новинарство на Универзитету у Иточном Сарајеву. Постоји оправдана потреба да будући новинари имају општа знања о тероризму и улози медија, било традиционалних или друштвених мрежа, које се у великој мјери користе за пропаганду, радикализацију и регрутовање присталица. У пракси, медији се, такође, користе од стране владиних институција како би добили подршку јавности за мјере супротстављања тероризму (Nacos, 2016). Затим, на студијском програму Политикологија и међународни односи на Универзитету у Источном Сарајеву тематика екстремизма и тероризма се изучава као једна наставна јединица на предмету ЕУ и спољна политика БиХ, те се на студијском програму Социологија такође тероризам изучава у оквиру једне наставне јединице на предмету Савремени политички системи.

На великом броју универзитета у свијету након терористичких напада на САД 11. септембра 2001. године долази до експанзије курсева (Silke, 2004), који тематику тероризма третирају из перспектива различитих научних дисциплина. Поред тога, на универзитетима се оснивају истраживачки 
центри који се искључиво баве истраживањем феномена тероризма. Сагледавајући стање у високом образовању на јавним универзитетима, наведени трендови се нису одразили на систем образовања и теме из студија тероризма су остале на маргинама политике образовања у Републици Српској.

\section{ЗАКљУЧАК}

У овом раду тражен је одговор на питања у којој мјери се тематика радикализације, насилног екстремизма и тероризма изучава у систему јавног образовања у Републици Српској, и да ли је постојећи систем образовања прилагођен потребама друштва и безбједносном окружењу.

Имајући у виду да је тематика екстремизма и радикализације значајно присутна у јавном дискурсу, посебно у медијима, политици, полицијским агенцијама и правосуђу у Републици Српској и БиХ у цјелини, заступљеност у систему образовања је изузетно ниска. У том контексту анализирани су основно, средње и високо образовање на првом циклусу студија на јавним универзитетима. Резултати истраживања су показали да наставни програми у основном и средњем образовању не садрже наставне теме о радикализацији, насилном екстремизму и тероризму. Што се тиче високог образовања, заступљеност ових тема у цјелини гледано је симболична са изузетком Факултета безбједносних наука Универзитета у Бањој Луци. У високом образовању евидентан је недостатак курсева из области тероризма на различитим студијским програмима. Феномен тероризма се изучава само у мањем броју студијских програма и то са минималним бројем наставних часова. Тероризам није само предмет интересовања професионалаца у сектору безбједности или правосуђу, већ има много шири друштвени и академски (мултидисциплинарни) контекст.

На основу предочене анализе стања треба дати одговор на друго истраживачко питање, односно, да ли су постојећи наставни планови и програми прилагођени друштвеним потребама и безбједносном амбијенту у коме се налази Република Српска и Босна и Херцеговина у цјелини. Посматрајући анализиране нивое образовања може се закључити да наставни планови не омогућавају адекватну припрему младих људи да разумију тероризам и сродне феномене. Ако се узме у обзир чињеница да је питање радикализације у Босни и Херцеговини значајан безбједносни проблем, затим да се спомене повратак ратника који су се борили на страни терориристичке организације ИСИЛ, те извршене терористичке нападе у Босни и Херцеговини - оправданост изучавања тероризма на свим нивоима образовања у Републици Српској није спорна. Превенција радикализације, насилног екстремизма и тероризма кроз систем образовања представља значајан друштвени ресурс који није у довољној мјери искориштен.

36 На основу резултата истраживања износе се одређене препоруке. Било би добро да се у основном и средњем образовању уведе предмет Безбједносна култура, а у оквиру тог предмета посвети пажња темама радикализације, насилног екстремизма и тероризма с акцентом на превенцију и рањивост младих приликом врбовања за приступање радикалним покретима и терористичким организацијама. 
Што се тиче високог образовања, препоручује се анализа наставних планова и студијских програма на јавним универзитетима, и цијени се да треба сагледати оправданост и потребу за увођењем нових предмета (обавезних или изборних) који би третирали наведену тематику из перспективе различитих научних дисциплина.

\section{ЛИТЕРАТУРА}

Altran, S., Axelrod, R., Davis, R., \& Fischhof, B. (2017). Challenges in Researching Terrorism from the Field. Science, 355 (6323), 352-354.

Азиновић, В. (2012). Увод у студије тероризма. Сарајево: Факултет политичких наука Универзитета у Сарајеву.

Азиновић, В., и Јусић, М. (2019). Нови зов рата у Сирији и босанскохерцеговачки контигент страних бораца. Сарајево: Атланска иницијатива.

Dongen, T. v. (2018). 130+(Counter-) Terrorism Research Centers-an Inventory. Perspectives on Terrorism, 12 (2), 86-124.

Факултет безбједносних наука. (2019). Укратко о факултету. Преузето 24.3.2019. https://fbn.unibl.org/ukratko-o-fakultetu/

Факултет безбједносних наука. (2019). Студијски програм Безбједност и криминалистика 2017/18. Преузето 10.3.2019. https://fbn.unibl.org/ studijski-program-bezbjednost-i-kriminalistika/

Филозофски факултет. (2019). Студијски програм Новинарство. Преузето 24.5.2019. http://www.ff.ues.rs.ba/files/docs/users/Urednik/Novinarstvosilabusi/medjunarodni-odnosi.pdf

Филозофски факултет. (2019). Студијски програм Политикологија и међународни односи. Преузето 22.5.2019. http://www.ff.ues.rs.ba/files/ docs/users/Urednik/Politikologija-silabusi/eu-i-spoljna-politika-bih.pdf

Филозофски факултет. (2019). Студијски програм Социологија. Преузето 22.5.2019. http://www.ff.ues.rs.ba/files/docs/users/Urednik/Sociologijasilabusi/savremeni-politicki-sistemi-sociologija.pdf

Gordon, A. (2004a). Applying Analytical Methods to Study Terrorism. International Studies Perspectives, 3 (8), 287-302.

Gordon, A. (2004b). Terrorism and Knowledge Growth: A Databases and Internet Analysis. In: Andrew Silke (Ed.). Research on Terrorism : Trends, Achievements \& Failures. London: Routledge, 104-118.

Hague, M. S. (2002). Government responses to terrorism: Critical views of their impacts on people and public administration. Public Administration Review, 62, 170-180.

Jackson, R. (2012). The Study of Terrorism 10 Years After 9/11: Successes, Issues, Challenges. Uluslararası iliş̧kiler, 32 (8), 1-16. 
Mahoney, C. (2017). More Data, New Problems: Audiences, Ahistoricity, and Selection Bias in Terrorism and Insurgency Research. International Studies Review, 20 (4), 589-614.

Мијалковић, С. (2014). Методологија пројектовања програма стручног усавршавања просветних радника из области безбедности. Безбједностполиција-грађани, 1-2, 47-61.

Mušić, S. (2016). Uloga obrazovanja u prevenciji nasilnog ekstremizma i radikalizma. Changing reality through education (str. 1-9). Mostar: Džemal Bijedić.

Nacos, B. (2016). Mass-mediated terrorism: Mainstream and digital media in terrorism and counterterrorism. Maryland: Rowman \& Littlefield.

Nacos, B. L. (2016). Terrorist Propaganda and the Mainstream Media. In: N. B. L, Terrorism and Counterterrorism (pp. 26). New York: Routledge.

Наставни план и програм Високе школе унутрашњих послова (2012). Бањалука: Висока школа унутрашњих послова.

Правни факултет. (2019). Кривично право. Преузето 22.3.2019. https://pf.unibl. org/krivicno-pravo/

Правни факултет. (2019). Криминологија са пенологијом. Преузето 22.3.2019. https://pf.unibl.org/kriminologija-sa-penologijom/

Правни факултет. (2019). Организовани криминалитет. Преузето 22.3.2019. https://pf.unibl.org/organizovani-kriminalitet/

Правни факултет. (2019). Студијски програми - силабуси за први циклус студија. Преузето 10.5.2019. https://www.pravni.ues.rs.ba/Download/Nastavni-Plan. pdf

Prislan, K., Černigoj, A., \& Lobnikar, B. (2018). Preventing radicalisation in the Western Balkans: The role of the police using a multi-stakeholder approach. Ravija za kriminalistiko in kriminologijo 69 (4), 257-268.

Ragazzi, F. (2017). Countering terrorism and radicalisation: Securitising social policy? Critical Social Policy, 37 (2), 163-179.

Reid, E. (1997). Evolution of a Body of Knowledge: An Analysis of Terrorism Research. Information Processing \& Management, 1 (33), 91-106.

Републички педагошки завод [РПЗ]. (2019). Наставни план и програм за основно образовање и васпитање у Републици Српској 2014. Преузето 25.5.2019. https://www.rpz-rs.org/sajt/doc/file/web_portal/05/5.2/Nastavni\%20 plan\%20i\%20program\%20za\%20osnovnu\%20skolu.pdf

Републички педагошки завод [РПЗ]. (2019). Наставни план и програм за средње образовање и васпитање. Преузето 22.3.2019. https://www.rpz-rs.org/22/ rpz rs/Za/srednje/obrazovanje/i/vaspitanje\#.XjXPH2hKjIU

Schuurman, B. (2018). Research on Terrorism, 2007-2016: A Review of Data, Methods, and Authorship. Terrorism and Political Violence, 1 (30), 1-16. 
Sheehan, I. S. (2012). Mapping Contemporary Terrorism Courses at Top-Ranked National Universities and Liberal Arts Colleges in the United States. Perspectives on Terrorism, 6 (2), 19-50.

Silke, A. (2001). The Devil you Know: Continuing Problems with Research on Terrorism. Terrorism and political Violence, 4 (13), 1-14.

Silke, A. (2004). An introduction to terrorism research. Research on terrorism: trends, achievements and failures (pp. 1-29). New York: Routledge.

Стајић, Љ., Мијалковић, С., \& Станаревић, С. (2006). Безбедносна култура младих - како живети безбедно. Београд: Драганић.

Станаревић, С., \& Бодин, М. (2014). Безбедносна култура као друштвени ресурс националне безбедности. Војно дело, 66, 84-104.

Thomas, P. (2016). Youth, terrorism and education: Britain's Prevent programme. International Journal of Life-Long Education, special issue: 'Youth, Social Crisis and Learning, 2 (35), 171-187.

UNDOC. (2017). Handbook on Children Recruited and Exploited by Terrorist and Violent Extremist Groups: The Role of the Justice System. Vienna: United Nationas.

United Nations Educational, Scientific and Cultural Organization. (2016). Teacher's Guide on the Prevention of VIOLENT EXTREMISM . Paris: UNESCO.

Универзитет у Бањој Луци. (2019). О Универзитету. Преузето 22.5.2019. http:// www.unibl.org/sr/univerzitet/o-univerzitetu

Универзитет у Источном Сарајеву. (2019). О Универзитету. Преузето 10.5.2019. https://www.ues.rs.ba/o-univerzitetu/

Закон о високом образовању Републике Српске - ЗоВО, Службени Гласник РС, број 73/10; 104/11; 84/12; 108/13; 44/15; 90/16 и 31/18).

Рад примљен: 15. 12. 2019.

Рад прихваћен: 13. 01. 2020. 